Article

\title{
How Climate-Induced Migration Entered the UN Policy Agenda in 2007-2010: A Multiple Streams Assessment
}

\author{
Elin Jakobsson \\ Swedish Institute of International Affairs, Sweden; E-Mail: elin.jakobsson@ui.se
}

Submitted: 14 May 2021 | Accepted: 9 September 2021 | Published: 22 October 2021

\begin{abstract}
In 2007, issues regarding climate-induced migration took a giant leap on the international policy agenda at the same time as a growth of interest in and salience of climate security. From having been a technical non-issue since the 1980s, climateinduced migration became one of the most emphasised consequences of climate change for a short period. After three years of fluidity in actors, institutions, and conceptual framings, issues of climate change and migration reached a formal recognition in the 2010 Cancún Adaptation Framework, marking a new era for policy discussions on climate-induced migration. This article sets out to show why this issue, which had been known to policymakers and academia for at least two decades, took such a major leap up the agenda at this specific point in time. The article draws from rich primary interview material together with an analytical framework based on the multiple streams framework in order to systematically answer this question. In doing so, the article primarily offers an empirical contribution to the knowledge and understanding of the specific agenda-setting mechanisms of climate-induced migration in an international policy context.
\end{abstract}

\section{Keywords}

climate change; climate-induced migration; global governance; multiple streams framework; windows of opportunity

\section{Issue}

This article is part of the issue "Climate Change and Security" edited by Yasuko Kameyama (National Institute for Environmental Studies, Japan) and Yukari Takamura (University of Tokyo, Japan).

(C) 2021 by the author; licensee Cogitatio (Lisbon, Portugal). This article is licensed under a Creative Commons Attribution 4.0 International License (CC BY).

\section{Introduction}

Issues regarding climate-induced migration took a giant leap on the international policy agenda in 2007-2010. The number of academic articles drastically increased (Findlay \& Geddes, 2011), and it seemed like every single humanitarian non-governmental organisation wanted to highlight the issue (Christian Aid, 2007; Kolmannskog, 2008; Warner et al., 2009), with politicians making grand statements (UNSC, 2007) and the media producing sensational headlines (Roberts, 2007).

However, policy discussions on climate-induced migration did not start in 2007. Instead, they are usually traced back to a United Nations Environment Programme (UNEP) report in 1985 coining the concept of "environmental refugees" (El-Hinnawi, 1985). The issue was then primarily the subject of an academic debate throughout the 1990s between "alarmists" and "sceptics," with the former emphasising the great impacts of climate change on migration movements and the latter contradicting this notion arguing that this conception was, in essence, a myth (Black, 1998; Gemenne, 2011; Myers, 1997). While the impacts of environmental change and natural disasters on human mobility were known, it was a technical, academic, and peripheral discussion up until 2007.

After a period of heightened fluidity in actors, structures, and conceptual framings, the period in focus here ends with the successful inclusion of $\S 14 \mathrm{f}$ of the Cancún Adaptation Framework (CAF) in late 2010. This short yet pivotal paragraph invites parties to "enhance understanding, coordination and cooperation with regard to climate change-induced displacement, migration and planned relocation, where appropriate, at the national, regional and international levels" (UN Framework Convention on Climate Change [UNFCCC], 2011, §14f). While this paragraph did not signal any substantial commitments, it provided a stepping stone for actors to elevate their work and advocacy on 
climate-induced migration from thereon (Nash, 2018). This was mirrored, not least with the establishment of the Nansen Initiative (a discursive and consultative platform gathering states and organisations; Kälin, 2012) in 2011. Moreover, climate-induced migration continued as a part of the work within the UNFCCC, and at COP21 in 2015, it was decided that the Task Force on Displacement (TFD) should develop recommendations on how to avert, minimise, and address climate change-related displacement (UNFCCC, 2015). A few years later, ideas and language from both the TFD recommendations (TFD, 2018) and the Nansen Protection Agenda-the 2015 outcome document of the Nansen Initiative (2015) - could be found mirrored in the 2018 Global Compact for Safe, Orderly, and Regular Migration (UN General Assembly, 2018) which indicates states' normative intent in the migration field even though it is not in any way binding legislation. All of this was done against the backdrop of $\S 14 f$ of the CAF.

In this article, I focus on the three years preceding the conference in Cancún. Using primary interview material with key practitioners at the time, I ask what conditions, mechanisms and confluent factors in the preceding years led up to this landmark recognition? It is not surprising as such that an issue is on the policy agenda. What is intriguing, however, is why this entered the agenda at this particular time, especially when the issue in question had been discussed as a problem for more than two decades. Research on the policy discussions on climate-induced migration partly or specifically covering this time has looked at aspects of mandate expansion (Hall, 2016b), institutional expansion (Simonelli, 2016), UNFCCC negotiations (Warner, 2011), securitisation (Boas, 2015), discourse and conceptualisation (Bettini, 2013; Bettini et al., 2016; Gemenne, 2011; Methmann \& Oels, 2015), and normative enterprises (Mayer, 2014). None, however, have tried to systematically explain why the issue had a boost at this specific time-rather than sooner or later. This article thus aims to add a perspective to the plethora of texts mentioned above. To understand the interaction between agency- and structural-based factors, this article employs the multiple streams framework (MSF) as theorised by Kingdon (1984) and its idea of a window of opportunity. In addition, this approach complements previous studies, which often use discourse analysis, norm diffusion theory, legal analysis, or institutional analysis to understand developments.

While there is no unified definition or agreement on the exact scope of the phenomenon of climate-induced migration, it generally refers to migration that has been fuelled by environmental degradation worsened by climate change (International Organization for Migration [IOM], 2009). However, this includes spectra on several levels, all of which spur debate on the scope and adequate solutions. One aspect is that of forced vs voluntary migration. For instance, when can climate-induced migration be considered forced displacement, and when is it voluntary mobility? Environmental migration is commonly intertwined with economic migration-which could be assumed to be relatively voluntary. On the other hand, migration does not have to be entirely voluntary just because it is not acute or fully forced (for more on this debate see, for example, lonesco et al., 2017; Kälin, 2010; Piguet, 2018). Climate-induced migration that is indeed forced is also subject to conceptual debate. However, most migration scholars agree that climate migrants are not refugees as they (only based on the threat from climate change) would not fulfil the requirements of the Refugee Convention. Nonetheless, they might be in need of protection (McAdam, 2012a). These are just a few examples that illustrate a complicated conceptual debate.

In any case, the range of climate-induced migration is wide and may include disaster displacement after sudden events such as wildfires, storms, or floods, as well as migration resulting from drought or sea-level rise (lonesco et al., 2017). Causes of migration and displacement are, however, always complex. In this case, empirical research has shown that rather than a direct cause of migration or displacement, natural disasters and environmental degradation are more often amplifiers working in intrinsic combination with context and other policies (Boas et al., 2019).

After this introductory section, the article moves on to outline the key aspects of the MSF. Section 3 applies the framework to the case of interest here, and Section 4 sums up the analysis and clarifies the conclusions and results.

\section{Multiple Streams and Policy Agendas}

There are moments when new policy issues make leaps up the policy agenda that seem underpinned by something intangible. A seminal model addressing this is found in Kingdon's (1984) work on American politics, in which the basic puzzle revolves around when an idea's time has come, often operationalised as the point when an issue enters the policy agenda. What starts out as merely different kinds of conditions ultimately boils down to the merging of the three streams (policy, problem, and politics) and the subsequent opening of a "window of opportunity." The MSF makes it possible to encompass both structural and agency-related aspects in an analysis and to explain why an issue enters the political agenda at a specific time point. Extensive and in-depth accounts of the MSF and its origins can be found elsewhere (Cohen et al., 1972; Kingdon, 1984), but the remainder of this section outlines the core features of the framework as employed here. In doing so, it also discusses how the concepts of the framework need and can be adapted for application to international policymaking. The MSF have, on multiple occasions, been adapted to the European Union level (see, for example, Ackrill et al., 2013; Herweg, 2015), but applications to the global level are still rare. 


\subsection{The Streams}

The MSF conceives of policymaking and its context as three streams: the problem stream, the policy stream, and the political stream. The problem stream consists primarily of different types of conditions that are perceived as problematic. The conditions are highlighted by indicators that are not in themselves necessarily problems. Problems are a matter of interpretation and should be solvable in order to distinguish them from mere conditions. Focusing events (e.g., disasters) may put the spotlight on certain problems and attract policymakers' attention (Kingdon, 1984). Indicators and focusing events are context-dependent and can easily be applied to the international context. However, it is not necessarily the same conditions that initiate problem construction on the international level, and similar conditions may be formulated into different kinds of problems depending on the policy context. For instance, a condition related to education might become a matter of teacher qualifications or taxation in the national context, but an issue of equality and human rights internationally. In the same line of reasoning, cross-border conditions such as trade, environment, or pandemics are more likely to be constructed into international problems than, say, poor road quality.

The policy stream is primarily about two things in Kingdon's model: policy communities and policy ideas. Policy communities consist of specialists in a given policy area who are directly or indirectly involved in policymaking. The policy ideas (also described as proposals, solutions, and alternatives) exist in the policy community's discussions and in the specialists' minds. As Kingdon (2011, Chapter 6) puts it, they float around in a "primeval soup" waiting to be picked up and connected to a policy problem. In the soup, ideas may also change, evolve, and form attachments with other ideas and alternatives. Individuals within the community who have an interest in spending their time and resources on advocating an idea or proposal, and chose to do so, are considered policy entrepreneurs (Kingdon, 1984). However, solutions and alternatives mean different things in the national and international context. Legislation is usually not an option at the international level, which instead must rely on soft law, diplomacy, and socialisation activities, for instance.

In Kingdon's model, the political stream encompasses such things as national mood, changes of administration, and turnover of key persons. Kingdon (2011, p. 146) explains national mood as "the climate in the country, changes in public opinion, or broad social movements." I have changed the concept here to "public mood" - meaning the set of values, standards, and issues against which the public, policymakers, and organisations measure new problems and solutions at a given point in time. Changes in administration and turnover of key persons do overlap but are somewhat different on the international level. However, changes in national governments influence not only national but also international politics as new governments may have different objectives to pursue in international fora. Administrations and key persons could also refer to the leadership of international organisations. For instance, leaders of international organisations are important advocates and have the authority to influence visions, strategies, and priorities in the international policy sphere. Moreover, in general, new personnel have the potential to provide new competence in global governance and national politics alike.

Against the background of this short outline of the streams, I will now linger upon two specific aspects. The first concerns linkages and framing, which, in my view, are key features in all three streams. The second concerns Kingdon's main explanation for agenda leaps: the window of opportunity.

\subsection{Framing and Linkages}

The exercise of framing determines the conceptual boundaries through which different elements of policymaking are understood (Entman, 1991). Framing always includes more or less intentional activities by actors, often referred to as policy entrepreneurs. When this is done through a larger degree of intention, it may be referred to as "strategic framing," where actors use the frames in order to try to make a new issue "fit" within a broader set of well-established values (Rhinard, 2017; see also Florini, 1996).

I argue that we can find features of framing in all three streams. Conditions in the problem stream are constructed into policy problems through interpretation and categorisation, which determines what kind of policy problem the condition is viewed as and determines public and political perception (Kingdon, 2011). The categorisation, in turn, determines the policy community, which institutional venue that should/could address it as well as possible solutions (Jakobsson, 2018). Framing in the problem stream is thus intertwined with framing in the policy stream. The evolvement and combination of ideas in the "policy primeval soup" interacts with and adapts to the categorisation of policy problems. Kingdon particularly points to "value acceptability," implying that a proposal is more likely to be considered seriously if it complies with the ideological and moral principles among the policy community specialists and stakeholders. Similarly, framing matters in the politics stream as agenda items that fit with the public mood at a particular point in time are promoted and thus more likely to enter the agenda, while items incompatible with the mood are likely left out (Kingdon, 2011).

Framing is usually not so explicitly dealt with in MSF analysis. However, I find it intrinsic in all parts of Kingdon's framework, albeit in other terms (as previously exemplified). Therefore, I have chosen to specifically highlight the implications of framing in the analysis as it adds helpful explanatory leverage. 
The next subsection brings the streams together and outlines how they may create a window of opportunity to advance issues on policy agendas.

\subsection{Windows of Opportunity}

The different streams may experience different kinds of alterations. New conditions, interpretations, or focusing events may arise in the problem stream, new communities may form in the policy stream, ideas may evolve or combine in the policy "primeval soup," new "moods" may arise in the political stream, or a turnover of key persons may occur. None of these factors, however, do in themselves firmly put an issue on the agenda. The key explanatory element of the MSF (in Kingdon's version) is the opening of a window of opportunity. Kingdon argues that the joint effect of confluent streams is particularly powerful in the agenda-setting process. Windows are short periods in which conditions in all three streams are favourable for a certain issue simultaneously, and through the active aid by policy, entrepreneurs make a substantial agenda leap (either onto the agenda or towards a decision). Windows are thus opened in the problem stream and/or in the policy stream, and actors in the policy stream seize those opportunities to open windows and/or make them productive.

Triggers for windows are often different kinds of contingencies, such as focusing events (such as disasters) or political alterations (e.g., turnover of central figures; see Kingdon, 1984). Policy entrepreneurs reside in the policy stream, waiting for problems-or political windows to open. While waiting, policy entrepreneurs work on different angles of preparation. One such activity is to cast light on the problem at hand, as Kingdon argues that it is beneficial if the policy issue is not completely new to policymakers when the window opens. Another activity is to prepare different kinds of alternatives and solutions that may be presented to policymakers at the right time and to familiarise policymakers with the alternatives beforehand through an exercise of "softening up" (Kingdon, 1984).

Something should be said regarding agendas and outcomes when adjusting the MSF to fit with international policymaking. First, this article uses $\S 14 f$ of the CAF as the outcome of the period in focus here. Even though the traditional outcome of merging streams and a window of opportunity would be a solution or political decision (not a symbolic recognition or a statement of intention), I argue that, in this context, it can indeed be considered an important outcome for the following reasons. To begin with, the foundation of Kingdon's study is to consider "not how issues are authoritatively decided by the president, Congress, or other decision-makers, but rather how they came to be issues in the first place" (Kingdon, 2011, p. 2). This implies that while formal decisions are often used as outcomes in MSF analysis, other outcomes could be of interest and still capture the essence of the approach. In addition, Kingdon makes a distinction between the governmental agenda and the decision agenda. The governmental agenda is the more general list of policy items under political discussion and consideration, while the decision agenda represents the issues that have come so far so that they become subject to decisive political decisions. In a global governance context, thinking in terms of a governmental agenda is more useful as binding decisions are not as common (as statements of intent or soft law) in the international as in the national arena. Therefore, it is reasonable to sometimes regard declarations of intention (such as $\S 14 \mathrm{f}$ of the (AF) as outcomes of windows of opportunity when applying the MSF to international politics, not least when such a declaration or recognition represents a groundbreaking point for future developments (as I have argued in this article).

Against the backdrop of the analytical framework, the next section takes on the empirical analysis.

\section{Confluent Streams in Climate-Induced Migration Politics}

This study draws from a rich primary material where the principal material consists of in-depth interviews with 23 practitioners and five academics. The interview material was assumed to be essential as the underlying values, strategies, conditions, and structures, as well as their interrelations, were sought afteraspects which are rarely done justice in official documents (Blaikie, 2010). For instance, the interviews explained the interrelations between different policy entrepreneurs, they gave information about informal conversations and motivations, and they described the policy entrepreneurs' feelings towards a variety of events and developments.

Twelve of the interviewed practitioners and four of the academics were directly and centrally involved in the developments in 2007-2010 and active at the UN Refugee Agency (UNHCR), the IOM, the Office of the High Commissioner for Human Rights (OHCHR), the International Federation of the Red Cross (IFRC), the World Bank, CARE international, or the Norwegian Refugee Council (NRC) during that period. The remaining seven interview objects are also representatives of academia and different organisations, both the organisations already mentioned but also the European Commission, the Internal Displacement Monitoring Center, the Nansen Initiative, and the Platform for Disaster Displacement. These persons are either currently working on issues of climate-induced migration, have done so in the past decade, or have exceptional insight, for various reasons, into the general policy developments at large but were not part of the core group of individuals in 2007-2010.

The interviews were conducted between 2016 and 2021 and were approximately one hour long. They revolved around key questions such as: 
- Do you perceive this period in time as pivotal to policy discussions on climate-induced migration? Why or why not?

- If yes, what were the underlying reasons for this?

- How would you describe the developments from this time?

- What were your strategies and objectives in your role at the time?

Against this backdrop, the interviewees were encouraged to speak freely about their experiences, memories, and personal conjectures. The interviews were transcribed and then categorised and analysed according to the analytical categories of the MSF and in line with a qualitative text analysis (Ritchie et al., 2014). The account below is intended to give justice to the material as a whole, but some representative quotes have been chosen for illustration.

The next four sections apply the MSF to the policy issue of climate-induced migration between 2007 and 2010. It considers the three streams and argues that there was a window of opportunity which helped climate-induced migration gain formal recognition on the policy agenda. Space constraints hinder a full account of the historical developments on climateinduced migration policy-and conceptual discussions. However, extensive reviews can be found elsewhere (see, for example, Castles, 2002; McAdam, 2012b; Piguet et al., 2011).

\subsection{The Problem Stream}

As already stated, environment and climate have always determined where humans can make a living. As such, it is a condition rather than a problem. In the 1980 s and 1990s, this started to be interpreted as a problem, primarily by academics but also by UN agencies such as the UNEP (El-Hinnawi, 1985). The underlying mechanism that increased the problematic aspect of this was the accelerating impacts of global warming on the global climate and the general awareness of climate change, which was expected to affect human mobility much more drastically than before.

In 2007-2010, climate-induced migration was conceived as problematic in at least three different ways. First, projections of "invasions" of climate refugees to the Global North was considered a potential security problem for states (WBGU, 2007). Second, it was a problem for the vulnerable people and affected societies (Swing, 2008). Third, actors soon realised that if climate change were to displace people across international borders, they would essentially find themselves in a legal void in terms of protection as they would not be covered by the Refugee Convention or similar frameworks (Biermann \& Boas, 2008).

A number of indicators highlighted the problematic aspects of climate-induced migration in the first two decades following its recognition. It was partly about increased understanding about the severity of the future potential impact of climate change on migration, but also about actual displacement events such as Hurricane Mitch in 1998 or Hurricane Katrina in 2005, which both displaced thousands (Kromm \& Sturgis, 2008; Westhoff et al., 2008). However, none of these indicators gave the problem the boost in salience needed to push it onto the agenda.

However, in 2007 and just before that, the interviews point to a number of events that significantly altered the problem stream. One such event was the 2004 Indian earthquake and tsunami, which illustrated, both to policymakers and the public, the human suffering and material destruction caused by natural disasters. The tsunami had different practitioners and organisations turn their gaze toward issues of disasters and displacement (interview from 9 February 2021; Goodwin-Gill \& McAdam, 2017).

Another circumstance that the interview material frequently highlighted was the IPCC fourth assessment report released in 2007, in which the IPCC highlighted migration as one of the most important consequences of climate change (IPCC, 2007). This was a significant acknowledgement as this report constituted the most comprehensive assessment of scientific knowledge on climate change there was at that point (Hulme, 2009). Yvo de Boer, then the executive secretary of the UNFCCC, held a press briefing in April 2007 (on the occasion of the launch of the report) where he particularly pointed to the "potential danger" posed by climate change if it were to trigger worldwide migration (UNFCCC, 2007b).

This was far from the only link made between state security and the (constructed) threat of climate migrants. Security linkages to climate-induced migration were present already in the 1990s through the "alarmist" (see above) strand of the climate migration debate. Myers (1997, p. 181), possibly the most prominent alarmist, argued that "environmental refugees could become one of the foremost human crises of our times" and that it could lead to turmoil, confrontation, conflict, and violence. However, the securitisation of climate-induced migration rocketed in 2007 when a number of reports feared a climate change-driven migration crisis that would "spiral out of control" (Christian Aid, 2007, p. 1), pose a "key threat" to international stability and security (WBGU, 2007, p. 11), and trigger migration at an "unprecedented scale" (UNSC, 2007; for discourse analyses of the apocalyptic notions of "climate refugees" see also Bettini, 2013; Methmann \& Oels, 2015).

It should be noted here that these "threat images" were framed by a general boost in a security focus on climate change and a securitisation of the same, not least within the UN system (Kurtz, 2012; Mobjörk et al., 2016). For instance, in 2007, the UN Security Council (UNSC) held a debate where it properly considered climate security for the first time, and in 2009, climate change was branded a security issue by a UN General Assembly resolution (Born, 2017; UNSC, 2007). 
The above examples all point to how indicators and focusing events contributed to the construction of a policy problem out of the condition that climate-induced migration and displacement constitutes. While this condition had been known for decades already, these events contributed to many more actors viewing this as a policy problem. The next section looks closely at the policy stream, policy communities, and entrepreneurs, as well as how different ideas regarding climate-induced migration evolve and combine into different types of policy issues with different kinds of alternatives and possible solutions.

\subsection{The Policy Stream}

One of the most significant happenings in the policy stream in 2007-2010 was forming a more distinct policy community regarding climate-induced displacement. These actors did not primarily represent security actors or organisations but humanitarian (e.g., IOM, UNHCR, NRC, OHCHR, CARE and IFRC), economic (e.g., World Bank), or academic actors (e.g., UN University).

Most of these organisations were not new to assisting migrants or persons struck by disaster, and some argue that they have had their eyes on environmental migration since at least the 1990s (interview from 31 March 2021; Goodwin-Gill \& McAdam, 2017; Ionesco \& Traore Chazalnoël, 2015). Nevertheless, all witnessed how this point in time brought salience to this issue on a completely new level, even for them. Most importantly, step by step, they found each other and started forming an advocacy community around climate-induced migration, which, in essence, remains to this day.

Gemenne (2011) and Warner (2011) have previously described how humanitarian actors during this time constructed the policy problem in terms of "the human face of climate change." The interview material aligns with the notion that bringing the human perspective into the climate change debate was a key objective as well as a potential niche for policy entrepreneurs. It was a general position in the policy community at the time that the debate needed a shift in focus from coral reefs and glaciers to human beings and to emphasise that that impact will lead to displacement and migration (interview from 8 March 2021). Interviewed 5 February 2021, one of the initiators of the Inter-Agency Standing Committee (IASC) sub-group said: "I mean, polar bears were the face of climate change, not people. We had a battleground to win, and that got us through."

The interviews also show several examples of how actors were worried about the security framing of climate-induced migration and thus wanted to steer the framing toward adaptation and humanitarian concerns rather than frames of threat issues to the west (interview from 5 February 2021). Nonetheless, however problematic, a security and threat-related framing strongly helped in getting policymakers' attention. As one interviewee put it: "These horror stories of an invasion have not been good, but it is alarmist enough, it gets people thinking" (interview from 26 February 2021).

An important part of forming a coordinated policy community on climate-induced migration was the establishment of an IASC task force on climate change with a sub-group focused on climate change migration and displacement. The group was created in 2008 and contained a number of humanitarian organisations, including IFRC, IOM, and UNHCR (Hall, 2016a). Members of this group described how they "began to run" with this issue once the IASC sub-group was established and how they quickly chose to go with promoting it as an adaptation issue (interviews from 5 February and 8 March 2021). While the IASC sub-group was central to the policy community on climate-induced migration at this time, involved policy entrepreneurs also connected through other networks, not least in conferences and research projects (Stal \& Warner, 2009). The entrepreneurial efforts depended somewhat on the position and background of the actor but included lobbying, socialising with stakeholders, writing submissions, organising side events, and providing an empirical basis.

The material shows that the advocacy activities during this period were focused on "softening up" policymakers regarding issues on climate-induced migration in order to have a future more formal recognition. Advocates also worked on combining ideas about the human implications of climate change and adaptation into ideas and alternatives regarding migration and mobility. Security notions were indeed present and brought attention and salience to the issue, particularly to politicians and the public. The wider climate security discourse is usually described as consisting of two separate strands, one focusing on the security implications for states and the other for humans (Mobjörk et al., 2016), a pattern that this case clearly mirrors. However, the interviews suggest that it was not primarily the state security framing, but rather the human security framing with an adaptation focus, that made policy entrepreneurs pursue issues of climate-induced migration in the UNFCCC and accomplish the inclusion of $\S 14 \mathrm{f}$ of the CAF. In this case, state security threat tactics offered some useful indicators and, in fact, imagined future focusing events (the feared invasion of "climate refugees"). In contrast, the human security narrative offered more feasible alternatives, greater value acceptability, and was also connected to something that was already underway-adaptation to climate change.

\subsection{The Political Stream}

This section moves on to the last stream, looking at elements such as public mood and key persons in the political administration (Kingdon, 1984).

The general change in mood regarding climate change significantly shifted in the public-as well as the political-sphere at this time. This was signalled, for example, by the status of the UNFCCC COPs. While 
those had previously been relatively small events suffering from constantly changing delegations with limited interest in climate change issues, COPs grew substantially, and delegations became more professional and goal-oriented (interview from 24 February 2021). As we have seen policy entrepreneurs describe in the previous section, this was also a time when the climate change debate shifted its focus from nearly exclusively being about mitigation to also including, even emphasising, adaptation (interview from 5 February 2021). This shift became evident with the 2007 Bali Action Plan (adopted at COP13), which for the first time equally concerned mitigation and adaptation (Hall, 2016a; UNFCCC, 2007a).

Interviews also mentioned the Al Gore film $A n$ Inconvenient Truth from 2006 as well as the change in US administration in 2009 with Barack Obama taking office as majorly important external conditions that switched the public and political approach to climate change into something substantially more serious than before. The framing of climate-induced migration as a climate change issue in general, and an adaptation issue in particular, made the issue a much better "fit" with the public and political mood.

In addition to the change in mood, new leadership had recently come to the UNHCR with High Commissioner Antonio Guterres. In 2007, Guterres (2007) said that "the picture is very worrying" considering impacts of climate change on displacement. In 2009, he said:

I am often asked to comment on doomsday predictions of waves of so-called "climate refugees" crashing upon the shores of the rich world. To this, I am saying: fear and speculation can only blur our vision and skew our response, which must be responsible and solidary. (Guterres, 2009)

Guterres was not directly part of the community of advocates, but he clearly had climate-induced migration as part of his personal agenda for UNHCR. He was inspired by Al Gore's film and by the idea of climate change as a "megatrend." In light of this idea, there was also an objective from Guterres to secure UNHCR's place as the dominant actor in the field of displacement, and an outstanding humanitarian agency, not least in relation to IOM. Guterres' statements on climate-induced migration set a tone in the debate and his efforts and visions guided a lot of UNHCR's work and view on climate-induced migration in those years (interviews from 3, 9, 15, 16 February and 8 and 22 March 2021; Goodwin-Gill \& McAdam, 2017; Hall, 2016b).

Having made an assessment of happenings in the three streams, the next section looks at the combined effects of the developments.

\subsection{A Window of Opportunity}

In 2007, the nature of discussions on climate-induced migration very swiftly changed, and the political audi- ence suddenly became "very receptive" (interview from 24 February 2021). Interviewed 8 March 2021, one practitioner stated that "it was like suddenly we put the foot on the accelerator and that's what set the stage so beautifully for Cancún."

At this time, a policy window opened for agenda advancement for climate-induced migration. Security connections and threat tactics boosted the issue in the policy stream, making it a security policy problem gaining attention from a broader public and political audience. At the same time, things simultaneously changed in the political sphere, with climate change at large gaining a significantly higher status, triggered by events such as Al Gore's film, more devoted and serious UNFCCC conferences, and a devoted high commissioner for refugees. In the same year, the Bali Action Plan signalled a shift in the climate change discussion from mitigation to adaptation, with adaptation taking (at least) an equally important part.

In the policy stream, a partly new policy community quickly formed in order to seize the opened window and push for a formal recognition of climate-induced migration in global governance-particularly in the UNFCCC context. Given that the main policy entrepreneurs were from humanitarian organisations, they were not particularly fond of the state security-and threat-related framing but rather wanted to push the human security angles. Not least because they saw an opportunity and a feasible way forward as that framing linked with the increased adaptation and risk management focus of the UN climate change negotiations. Several interviewees described how they knew that an adaptation framework was coming up for negotiation in the UNFCCC context and that they saw this as an entry point to try to push the issue.

I argue here that without all the components mentioned above happening simultaneously, it would have been much less likely that climate-induced migration would have had such a boost on the international policy agenda in 2007-2010 or that it would have gained formal recognition in the CAF. First, there were successful framings in both state security and human security connections, which gained traction. Second, the public and political spheres were receptive, partly because of the increased interest in climate change. Third, key individuals such as Antonio Guterres lent dignity to the arguments. Fourth, a coordinated humanitarian and academic group of policy entrepreneurs did the groundwork of "softening up" policymakers, providing an empirical basis, and preparing alternatives. Most importantly, the policy entrepreneurs seized the opportune moment that presented itself. All of these factors were intertwined, simultaneous and created joint effects at a particular period in time.

Having argued that this approach offers a plausible explanation for why the policy push regarding climateinduced migration happened at this specific point in time, the conclusions offer suggestions for why it did 
not happen earlier. For instance, security framings of climate-induced migration had already been made in the 1990s (see, for example, Myers, 1997), and several big natural disasters such as Hurricane Mitch in Central America in 1998 displaced thousands of people (Westhoff et al., 2008). However, the public and political interest in climate change were not strong enough, and policy entrepreneurs were too few and uncoordinated.

\section{Conclusions}

In this study, I have argued that climate-induced migration had its formal recognition on the global governance agenda due to a successfully used window of opportunity. The assessment shows how there were joint effects from problem definition, the policy community, framing, and key persons, which resulted in a substantial agenda leap for this issue in 2007-2010.

The conjunctures generated here ties back to other prominent works within this debate in different ways, and for the most part, this study complements rather than contradicts previous findings. For instance, this study gives some theoretical framing to the already extremely detailed accounts of the UNFCCC developments during these years made by Warner (2011). Moreover, the findings align with Hall's description of the policy community (i.e., the humanitarian community) as exceptionally well-coordinated at the time (Hall, 2016a) and how some actors attempted to expand their mandates to do so (Hall, 2016b). This article puts these findings in a wider, more contingency-based context and uses them for a somewhat different explanatory aim.

On a different note, the tension between different security-related narratives on climate-induced migration is also explored in Bettini et al. (2016). As does this study, the authors notice how a conceptual shift from "climate refugees" (which tend to be more state security-related) to "climate migration" (which is more adaptation- and human security-related) have taken place. But where this study emphasises how policy entrepreneurs have used this shift for policy advancements, Bettini et al. (2016) raise concerns regarding how the shift risks making issues of climate justice invisible.

A direct compliment to the existing research is made between this article and the work of Nash (2018). Instead of using $\S 14 f$ of the CAF as an endpoint, as I have done here, Nash uses it as a starting point and follows the policy developments, especially within the UNFCCC, up until the Paris Agreement in 2015. So, where Nash shows how Cancún cemented climate-induced migration in the UNFCCC setting and the importance of this venue for the subsequent policy developments, this study explains the mechanisms through which $\S 14 \mathrm{f}$ materialised in the first place. Furthermore, where this study illustrates the formation of a group of policy entrepreneurs from different organisations, how they started to become aware of the issue of climate-induced migration and lobbied for its inclusion in the CAF, Nash underscores how this group ramped up their work after 2010 and continued to push for policy developments towards COP21 in Paris.

The benefit of employing the MSF in this study is that it explains why this agenda leap came at this particular point in time even though climate-induced migration as a phenomenon and possible policy problem had been known in global governance and academia since at least the mid-80s. Moreover, the MSF allows for the consideration of both structural and agency-based factors. While there are still to this day no international viable and comprehensive solutions or plans to address climate-induced migration, $\S 14 \mathrm{f}$ of the CAF (which is defined as the central outcome of this window) has been a landmark for later institutional, political, and conceptual developments on the issue.

In addition, this study illustrates interesting and specific points on the use of the climate security concept as such. We have seen that the issue of climateinduced migration is related to the climate security debate through two somewhat contradictory security narratives on climate-induced migration. One which foresaw a threat to international security in the potentially massive waves of migrants. Another focused on the security of the displaced, describing the vulnerable climateinduced migrants as "the human face of climate change." In sum, this article shows that the first state-security narrative connected the streams and opened a window, while the other human-security narrative made the issue of climate-induced migration find its way forward in the policy primeval soup to a clear place on the policy agenda.

Future research could continue to develop and adapt the MSF for international relations and global governance and to further explore the importance of framing in this context. For practitioners, this conclusion implies that framing matters for policy advancement and that policy entrepreneurs should be attentive to when problem, policy, and politics may merge and how they can make use of the potential windows of opportunity that may open.

\section{Acknowledgments}

The author would like to thank the three anonymous reviewers for their insightful comments, which helped improve the article substantially.

\section{Conflict of Interests}

The author declares no conflict of interest.

\section{References}

Ackrill, R., Kay, A., \& Zahariadis, N. (2013). Ambiguity, multiple streams, and EU policy. Journal of European Public Policy, 20(6), 871-887.

Bettini, G. (2013). Climate barbarians at the gate? A critique of apocalyptic narratives on "climate refugees." Geoforum, 45, 63-72. 
Bettini, G., Nash, S. L., \& Gioli, G. (2016). One step forward, two steps back? The fading contours of (in)justice in competing discourses on climate migration. The Geographical Journal, 183(4), 348-358.

Biermann, F., \& Boas, I. (2008). Protecting climate refugees: The case for a global protocol. Environment, 50(6), 2-9.

Black, R. (1998). Refugees, environment and development. Longman.

Blaikie, N. W. H. (2010). Designing social research: The logic of anticipation. Polity Press.

Boas, I. (2015). Climate migration and security: Securitisation as a strategy in climate change politics. Routledge.

Boas, I., Farbotko, C., Adams, H., Sterly, H., Bush, S., van der Geest, K., Wiegel, H., Ashraf, H., Baldwin, A., Bettini, G., Blondin, S., de Bruijn, M., Durand-Delacre, D., Fröhlich, C., Gioli, G., Guaita, L., Hut, E., Jarawura, F. X., Lamers, M., ... Hulme, M. (2019). Climate migration myths. Nature Climate Change, 9(12), 901-903.

Born, C. (2017). A resolution for a peaceful climate: Opportunities for the UN Security Council (SIPRI Policy Brief). Stockholm International Peace Research Institute.

Castles, S. (2002). Environmental change and forced migration: Making sense of the debate (Working Paper No. 70). UNHCR.

Christian Aid. (2007). Human tide: The real migration crisis.

Cohen, M., March, J., \& Olsen, J. (1972). A garbage can model of organizational choice. Administrative Science Quarterly, 17, 1-25.

El-Hinnawi, E. (1985). Environmental refugees. UNEP.

Entman, R. M. (1991). Framing U.S. coverage of international news: Contrasts in narratives of the KAL and Iran air incidents. Journal of Communication, 41(4), 6-27.

Findlay, A., \& Geddes, A. (2011). Critical views on the relationship between climate change and migration: Some insights from the experience of Bangladesh. In É. Piguet, A. Pécoud, \& P. de Guchteneire (Eds.), Migration and climate change (pp. 138-159). Cambridge University Press.

Florini, A. (1996). The evolution of international norms. International Studies Quarterly, 40, 363-389.

Gemenne, F. (2011). How they became the human face of climate change. Research and policy interactions in the birth of the 'environmental migration' concept. In É. Piguet, A. Pécoud, \& P. de Guchteneire (Eds.), Migration and climate change (pp. 225-259). Cambridge University Press.

Goodwin-Gill, G. S., \& McAdam, J. (2017). UNHCR \& climate change, disasters and displacement. UNHCR.

Guterres, A. (2007). Keynote Speech by Mr António Guterres, united nations high commissioner for refugees, at the third symposium on corporate social responsibility and humanitarian assistance, Tokyo, 26 November 2007 [Speech transcript]. UNHCR. https:// www.unhcr.org/admin/hcspeeches/476132d911/

keynote-speech-mr-antonio-guterres-united-

nations-high-commissioner-refugees.html

Guterres, A. (2009). Climate change, migration and displacement. Statement by António Guterres, UN high commissioner for refugees at UNFCCC sideevent, Bella Center, Copenhagen 16 December 2009 [Speech transcript]. IOM. https://www.iom.int/sites/ default/files/jahia/webdav/shared/shared/mainsite/ activities/env_degradation/statement_guterres.pdf

Hall, N. (2016a). A catalyst for cooperation: The interagency standing committee and the humanitarian response to climate change. Global Governance, 22(3), 369-387.

Hall, N. (2016b). Displacement, development, and climate change: International organisations moving beyond their mandates. Routledge.

Herweg, N. (2015). Explaining European agenda-setting using the multiple streams framework: The case of European natural gas regulation. Policy Sciences, 49(1), 13-33.

Hulme, M. (2009). Mediated messages about climate change. Reporting the IPCC fourth assessment in the UK print media. In T. Boyce \& J. Lewis (Eds.), Climate change and the media (pp. 117-128). Peter Lang.

International Organization for Migration. (2009). Migration, environment and climate change: Assessing the evidence.

Ionesco, D., Mokhnacheva, D., \& Gemenne, F. (2017). The atlas of environmental migration. Routledge; IOM.

Ionesco, D., \& Traore Chazalnoël, M. (2015). The role of the International Organization for Migration in the international governance of environmental migration. In K. Rosenow-Williams \& F. Gemenne (Eds.), Organizational Perspectives on Environmental Migration (pp. 108-125). Routledge.

IPCC. (2007). Climate change 2007: Synthesis report.

Jakobsson, E. (2018). Norm acceptance in the international community: A study of disaster risk reduction and climate-induced migration [Unpublished doctoral thesis]. Stockholm University.

Kälin, W. (2010). Conceptualising climate-induced migration. In J. McAdam (Ed.), Climate change and displacement-Multidisciplinary perspectives (pp. 81-104). Hart Publishing.

Kälin, W. (2012). From the Nansen principles to the Nansen Initiative. Forced Migration Review, 41, 48-49.

Kingdon, J. W. (1984). Agendas, alternatives, and public policies. Little Brown and Company.

Kingdon, J. W. (2011). Agendas, alternatives, and public policies (2nd ed.). Longman.

Kolmannskog, V. O. (2008). Future floods of refugeesA comment on climate change, conflict and forced migration. Norwegian Refugee Council.

Kromm, C., \& Sturgis, S. (2008). Hurricane Katrina and the guiding principles on internal displacement. A global 
human rights perspective on a national disaster. Institute for Southern Studies.

Kurtz, G. (2012). Securitisation of climate change in the United Nations 2007-2010. In J. Scheffran, M. Brzoska, H. G. Brauch, P. M. Link, \& J. Schilling (Eds.), Climate change, human security and violent conflict. Challenges for societal stability (pp. 669-684). Springer.

Mayer, B. (2014). "Environmental migration" as norm entrepreneurship: Is it going to work? Refuge, 29(2), 1-21.

McAdam, J. (2012a). Climate change, forced migration, and international law. Oxford University Press.

McAdam, J. (Ed.). (2012b). Climate change and displacement: Multidisciplinary perspectives. Hart Publishing.

Methmann, C., \& Oels, A. (2015). From "fearing" to "empowering" climate refugees: Governing climateinduced migration in the name of resilience. Security Dialogue, 46(1), 51-68.

Mobjörk, M., Gustafsson, M.-T., Sonnsjö, H., Van Baalen, S., Dellmuth, L., \& Bremberg, N. (2016). Climate-related security risks. Towards an integrated approach. Stockholm International Peace Research Institute.

Myers, N. (1997). Environmental refugees. Population and Environment, 19(2), 167-182.

Nansen Initiative. (2015). Agenda for the protection of cross-border displaced persons in the context of disasters and climate change (Volume 1 ).

Nash, S. L. (2018). From Cancun to Paris: An era of policy making on climate change and migration. Global Policy, 9(1), 53-63.

Piguet, E. (2018). Theories of voluntary and forced migration. In R. McLeman \& F. Gemenne (Eds.), Routledge handbook of environmental displacement and migration (pp. 17-28). Routledge.

Piguet, É., Pécoud, A., \& Dé Guchteneire, P. (Eds.). (2011). Migration and climate change. Cambridge University Press.

Rhinard, M. (2017). Strategic framing and the European Commission. In N. Zahariadis \& L. Buonanno (Eds.), Routledge handbook of European public policy (pp. 308-322). Routledge.

Ritchie, J., Lewis, J., McNaughton Nicholls, C., \& Ormston, R. (Eds.). (2014). Qualitative research practice: A guide for social science students and researchers (2nd ed.). SAGE.

Roberts, A. (2007, September 14). Islanders without an island. What will become of Tuvalu's climate refugees? Spiegel International. https://www. spiegel.de/international/world/islanders-withoutan-island-what-will-become-of-tuvalu-s-climaterefugees-a-505819.html

Simonelli, A. (2016). Governing climate induced migra- tion and displacement: IGO expansion and global policy implications. Palgrave Macmillan.

Stal, M., \& Warner, K. (2009). The way forward. Researching the environment and migration nexus. United Nations University, Institute for Environment and Human Security.

Swing, W. L. (2008). Environment, forced migration and social vulnerability: Identifying problems and challenges [Keynote address]. Environment, Forced Migration and Social Vulnerability International Conference, Bonn, Germany.

Task Force on Displacement. (2018). Report of the task force on displacement.

UN Framework Convention on Climate Change. (2007a). Bali Action Plan. In Report of the Conference of the Parties on its thirteenth session, held in Bali, from 3 to 15 december 2007-Addendum. Part two: Action taken by the Conference of the Parties at its thirteenth session (pp. 3-6).

UN Framework Convention on Climate Change. (2007b, April 6). UNFCCC executive secretary says significant funds needed to adapt to climate change impacts [Press Release]. https://unfccc.int/files/ press/news_room/press_releases_and_advisories/ application/pdf/070406_pressrel_english.pdf

UN Framework Convention on Climate Change. (2011). Report of the Conference of the Parties on its sixteenth session, held in Cancun from 29 November to 10 December 2010 (FCCC/CP/2010/7/Add.1).

UN Framework Convention on Climate Change. (2015). Decision 1/CP.21: Adoption of the Paris Agreement (FCCC/CP/2015/10/Add.1).

UN General Assembly. (2018). Global compact for safe, orderly and regular migration (A/RES/73/195).

UNSC. (2007, April 17). Security Council holds first-ever debate on impact of climate change on peace, security, hearing over 50 speakers. https://www.un.org/ press/en/2007/sc9000.doc.htm

Warner, K. (2011). Climate change induced displacement: Adaptation policy in the context of the UNFCCC climate negotiations. UNHCR, Division of International Protection.

Warner, K., Ehrhart, C., de Sherbinin, A., Adamo, S., \& Chai-Onn, T. (2009). In search of shelter: Mapping the effects of climate change on human migration and displacement. CARE; Columbia University; UNHCR; UNU-EHS; World Bank.

WBGU. (2007). World in transition: Climate change as a security risk. Summary for policy-makers.

Westhoff, W. W., Lopez, G. E., Zapata, L. B., Wilke Corvin, J. A., Allen, P., \& McDermott, R. J. (2008). Reproductive health education and services needs of internally displaced persons and refugees following disaster. American Journal of Health Education, 39(2), 95-103. 


\section{About the Author}

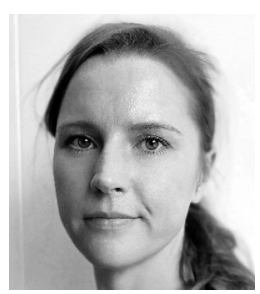

Elin Jakobsson is a post-doc researcher at the Swedish Institute of International Affairs in Stockholm, Sweden. She holds a PhD in international relations from Stockholm University. Her research interests concern climate-induced migration, societal security, international norm diffusion, and global governance. She is also a teacher in international cooperation at Stockholm University and has previously worked with the Swedish Migration Agency. 